\title{
Immunologic basis for long HCDR3s in broadly neutralizing antibodies against HIV-1
}

\section{Lei Yu ${ }^{1}$ and Yongjun Guan ${ }^{1,2 *}$}

1 Division of Basic Science and Vaccine Research, Institute of Human Virology, University of Maryland School of Medicine, Baltimore, MD, USA

${ }^{2}$ Department of Microbiology and Immunology, University of Maryland School of Medicine, Baltimore, MD, USA

\section{Edited by:}

Zhixin Zhang, University of Nebraska Medical Center, USA

Reviewed by:

Zhixin Zhang, University of Nebraska Medical Center, USA

Nina Luning Prak, Trustees of the University of Pennsylvania, USA

\section{*Correspondence:}

Yongjun Guan, Division of Basic

Science and Vaccine Research, Institute of Human Virology,

University of Maryland School of Medicine, 725 West Lombard Street, Baltimore, MD 21201, USA e-mail:yjguan@ihv.umaryland.edu
A large number of potent broadly neutralizing antibodies (bnAbs) against HIV-1 have been reported in recent years, raising hope for the possibility of an effective vaccine based on epitopes recognized by these protective antibodies. However, many of these bnAbs contain the long heavy chain complementarity-determining region 3 (HCDR3), which is viewed as an obstacle to the development of an HIV-1 vaccine targeting the bnAb responses. This minireview summarizes the current literature and discusses the different potential immunologic mechanisms for generating long HCDR3, including D-D fusion, VH replacement, long $\mathrm{N}$ region addition, and skewed $\mathrm{D}-\mathrm{J}$ gene usage, among which potential $\mathrm{VH}$ replacement products appear to be significant contributors. $\mathrm{VH}$ replacement occurs through recombinase activated gene-mediated secondary recombination and contributes to the diversified naïve $\mathrm{B}$ cell repertoire. During VH replacement, a short stretch of nucleotides from previously rearranged $\mathrm{VH}$ genes remains within the newly formed $\mathrm{HCDR} 3$, thus elongating its length. Accumulating evidence suggests that long HCDR3s are present in significant numbers in the human mature naïve $B$ cell repertoire and are primarily generated by recombination during B cell development. These new observations indicate that long HCDR3s, though low in frequency, are a normal feature of the human antibody naïve repertoire and they appear to be selected to target conserved epitopes located in deep, partially obscured regions of the HIV-1 envelope trimer. Therefore, the presence of long HCDR3 sequences should not necessarily be viewed as an obstacle to the development of an HIV-1 vaccine based upon bnAb responses.

Keywords: VH replacement, HIV-1, broadly neutralizing antibodies, long HCDR3, immunologic mechanism, vaccines

\section{INTRODUCTION}

The development of a protective HIV-1 vaccine is believed to be the best hope in the battle against HIV-1/AIDS. However, this goal remains elusive after 30 years of intense effort. Broadly neutralizing antibodies (bnAbs) against the HIV-1 envelope protein (Env) can be protective, as shown by passive immunization studies in nonhuman primates and humanized-mouse models (1-11). However, no HIV-1 vaccine candidate has been able to elicit a bnAb response. In the last 5 years, many novel bnAbs have been identified and are actively being pursued as templates for the rational design of an effective HIV-1 vaccine (12-20). Understanding the immunologic basis for the generation of these bnAb should help the design of an effective HIV-1 vaccine.

\section{HIV-1 BROADLY NEUTRALIZING ANTIBODIES HAVE UNIQUE FEATURES}

Many potent bnAbs have been isolated and characterized from multiple subjects in the last 5 years (21-33), mainly due to the application of efficient methods for isolation of human monoclonal antibodies (mAbs) (27, 30, 34-37). These new HIV-1 bnAbs are much more potent and broader than previously described neutralizing Abs. With the elucidation of crystal structures of the HIV-1 Env trimer and gp120-antibody complexes (38-41), the vulnerable epitopes on the HIV-1 Env targeted by bnAbs are becoming clear. These new bnAbs can be categorized into four groups (Table 1). The first group is CD4 binding site (CD4bs) bnAbs represented by "VRC01-like" bnAbs $(26,28,31,32)$ that block Env binding to the primary receptor $\mathrm{CD} 4$. The second group includes the PGT series (29, 42-44), "PG9-like" bnAbs [PG9, PG16 (30), and CH01-04 (21)], which recognize both protein and glycan elements involving the V1V2 and V3 regions of gp120. The third group includes the recently described PGT151 series of bnAbs and the redefined 8ANC195 bnAb, which recognize glycan-related, gp120 and gp41 bridging regions (45-47). The fourth group targets the membrane-proximal external region (MPER) on gp41 and includes the antibodies 2F5, 4E10, 10E8, and $\operatorname{M66.6}(24,48,49)$. These bnAbs collectively neutralize a majority of highly diverse HIV-1 strains. The new bnAbs and the recent crystal structure of HIV-1 Env trimer in complex with bnAbs have shed light on epitopes that could represent the basis for an Ab-based HIV-1 vaccine design. However, there are some common features of bnAbs that pose challenges to the development of a bnAb-based AIDS vaccine [reviewed in Ref. $(20,50)$ and Table 1 ].

The first is that the new HIV-1 bnAbs are highly somatically mutated, especially in the variable heavy chain region $(\mathrm{VH})$ genes $(21,22,26,28-32,53)$. This is in contrast with other human immunoglobulin G (IgG) antibodies and HIV-specific IgG antibodies with limited neutralizing activity $(27,54,55)$. Many of 
Table 1 | Characteristics of the heavy chain V-gene of HIV-1 broadly neutralizing antibody.

\begin{tabular}{|c|c|c|c|c|c|c|c|c|c|c|}
\hline \multirow{2}{*}{$\begin{array}{l}\text { Category based on } \\
\text { epitope cluster }\end{array}$} & \multicolumn{2}{|c|}{ HIV-1 bnAb } & \multicolumn{3}{|c|}{ Heavy chain genes } & \multicolumn{2}{|c|}{ HCDR3 (IMGT) } & \multicolumn{2}{|c|}{ VH somatic mutation } & \multirow{2}{*}{$\begin{array}{l}\text { Auto/poly } \\
\text { reactivity** }\end{array}$} \\
\hline & Class & Clone & V gene & D gene & J gene & Length & $\begin{array}{l}\text { Potential VH } \\
\text { replacement* }\end{array}$ & $\begin{array}{l}\text { No. of } \\
\text { nt }(\%)\end{array}$ & $\begin{array}{l}\text { No. of } \\
\text { AA (\%) }\end{array}$ & \\
\hline \multirow{24}{*}{$\begin{array}{l}\text { CD4 binding site } \\
\text { (CD4bs) }\end{array}$} & b12 & b12 & IGHV1-3 & D1-1 & $\mathrm{J} 6^{*} 03$ & 20 & No & $35(12.2)$ & $20(20.8)$ & No \\
\hline & VRC01 & 3BNC117 & IGHV1-2 & D6-25 & $\mathrm{J} 6 * 04$ & 12 & Yes & $75(26.0)$ & $34(35.4)$ & Yes \\
\hline & & 3BNC60 & IGHV1-2 & D3-3 & $\mathrm{J} 6 * 04$ & 12 & Yes & $82(28.5)$ & $38(39.6)$ & Yes \\
\hline & & PG19 & IGHV1-2 & D6-25 & $\mathrm{J} 1{ }^{*} 01$ & 13 & ND & 66 (22.9) & 30 (31.3) & NR \\
\hline & & VRC01 & IGHV1-2 & D2-21 & $\mathrm{J} 2 * 01$ & 14 & Yes & $91(31.6)$ & $40(41.7)$ & Neg.R \\
\hline & & VRC02 & IGHV1-2 & D5-12 & $\mathrm{J} 2{ }^{*} 01$ & 14 & Yes & 92 (31.9) & 38 (39.6) & Neg.R \\
\hline & & VRC23 & IGHV1-2 & D5-24 & $\mathrm{J} 4{ }^{*} 02$ & 14 & ND & 62 (21.5) & 30 (31.3) & NR \\
\hline & & PG20 & IGHV1-2 & D3-10 & $\mathrm{J} 1{ }^{*} 01$ & 15 & ND & $69(24.0)$ & 36 (37.5) & NR \\
\hline & & $12 \mathrm{~A} 12$ & IGHV1-2 & D4-17 & $\mathrm{J} 2{ }^{*} 01$ & 15 & No & $64(22.2)$ & $33(34.4)$ & Yes \\
\hline & & $12 \mathrm{~A} 21$ & IGHV1-2 & D1-26 & $\mathrm{J} 2{ }^{*} 01$ & 15 & Yes & $60(20.8)$ & 30 (31.3) & Yes \\
\hline & & $\mathrm{CH} 30$ & IGHV1-2 & D3-16 & $\mathrm{J} 4{ }^{*} 02$ & 15 & Yes & $69(24.0)$ & 37 (38.5) & Neg.R \\
\hline & & $\mathrm{CH} 31$ & IGHV1-2 & D5-12 & $\mathrm{J} 4{ }^{*} 02$ & 15 & Yes & $72(25.0)$ & 37 (38.5) & Neg.R \\
\hline & & VRC03 & IGHV1-2 & D2-21 & $\mathrm{J} 4{ }^{*} 02$ & 16 & Yes & $85(29.5)$ & 39 (40.6) & Neg.R \\
\hline & & VRC-PG04 & IGHV1-2 & D2-8 & $\mathrm{J} 2 * 01$ & 16 & No & $84(29.2)$ & 42 (43.8) & Neg.R \\
\hline & & VRC-PG04b & IGHV1-2 & D2-15 & $\mathrm{J} 2{ }^{*} 01$ & 16 & Yes & $82(28.5)$ & 42 (43.8) & Neg.R \\
\hline & & VRC06 & IGHV1-2 & D2-21 & $\mathrm{J} 5{ }^{*} 02$ & 17 & ND & $88(30.6)$ & 46 (47.9) & NR \\
\hline & & NIH45-46 & IGHV1-2 & D1-26 & $\mathrm{J} 2{ }^{*} 01$ & 18 & Yes & $94(32.6)$ & 39 (40.6) & Yes \\
\hline & & 3BC176 & IGHV1-2 & D5-12 & $\mathrm{J} 3{ }^{*} 01$ & 21 & ND & $69(24.0)$ & $34(35.4)$ & Yes \\
\hline & & 3ВС315 & IGHV1-2 & D5-12 & $\mathrm{J} 3{ }^{*} 01$ & 21 & ND & $48(16.7)$ & $24(25.0)$ & Yes \\
\hline & 8ANC131 & 8ANC131 & IGHV1-46 & D3-16 & J6*01 & 18 & No & $74(26.0)$ & $38(40.0)$ & Yes \\
\hline & & 8ANC134 & IGHV1-46 & D3-16 & J6*01 & 18 & No & $76(26.7)$ & 37 (38.9) & Yes \\
\hline & & $1 \mathrm{NC9}$ & IGHV1-46 & D5-24 & $\mathrm{J} 4{ }^{*} 02$ & 21 & Yes & $71(24.7)$ & 36 (37.5) & Yes \\
\hline & & 1B2530 & IGHV1-46 & D3-10 & $\mathrm{J} 5 * 02$ & 18 & Yes & $80(27.8)$ & 39 (40.6) & Yes \\
\hline & $\mathrm{CH} 103$ & $\mathrm{CH} 103$ & IGHV4-61 & D4-23 & $\mathrm{J} 4 * 01$ & 15 & ND & 45 (15.8) & $19(20.0)$ & Yes \\
\hline \multirow{17}{*}{$\begin{array}{l}\text { Glycan-dependent, } \\
\text { V1/N2 and V3 related } \\
\text { (QNE/supersite) }\end{array}$} & $2 \mathrm{G} 12$ & $2 \mathrm{G} 12$ & IGHV3-21 & D1-26 & $\mathrm{J} 3{ }^{*} 01$ & 16 & ND & $61(21.2)$ & $31(32.3)$ & Yes \\
\hline & PGT145 & PGT145 & IGHV1-8 & D4-17 & $\mathrm{J} 6^{*} 02$ & 33 & Yes & $48(16.7)$ & $27(28.1)$ & NR \\
\hline & & PGT141 & IGHV1-8 & D4-17 & J6*02 & 34 & Yes & $46(16.0)$ & $27(28.1)$ & NR \\
\hline & & PGT142 & IGHV1-8 & D4-17 & $\mathrm{J} 6 * 02$ & 34 & Yes & 47 (16.3) & $29(30.2)$ & NR \\
\hline & PG9 & $\mathrm{CH} 01$ & IGHV3-20 & D3-10 & $\mathrm{J} 2 * 01$ & 26 & Yes & $48(16.7)$ & $28(29.2)$ & Neg.R \\
\hline & & $\mathrm{CHO} 2$ & IGHV3-20 & D3-10 & $\mathrm{J} 2 * 01$ & 26 & ND & $41(14.2)$ & $22(22.9)$ & Neg.R \\
\hline & & PG9 & IGHV3-33 & D3-3 & $\mathrm{J} 6{ }^{*} 03$ & 30 & No & $40(15.1)$ & 18 (18.9) & Neg.R \\
\hline & & PG16 & IGHV3-33 & D3-3 & $\mathrm{J} 6 * 03$ & 30 & No & 43 (14.9) & 21 (21.9) & Neg.R \\
\hline & PGT128 & PGT135 & IGHV4-39 & D3/OR15-3a & $\mathrm{J} 5 * 02$ & 20 & Yes & 54 (18.6) & $28(28.9)$ & NR \\
\hline & & PGT137 & IGHV4-39 & D2-15 & $\mathrm{J} 5 * 02$ & 20 & Yes & 67 (23.0) & 32 (33.0) & NR \\
\hline & & PGT125 & IGHV4-39 & D3/OR15-3a & $\mathrm{J} 5 * 02$ & 21 & Yes & $60(20.6)$ & $28(28.9)$ & NR \\
\hline & & PGT127 & IGHV4-39 & D3-16 & $\mathrm{J} 5 * 02$ & 21 & Yes & 46 (15.8) & $25(25.8)$ & NR \\
\hline & & PGT128 & IGHV4-39 & D3-10 & $\mathrm{J} 5$ *02 & 21 & Yes & 59 (20.3) & 29 (29.9) & NR \\
\hline & PGT121 & PGT121 & IGHV4-59 & D3-3 & $\mathrm{J} 6$ *03 & 26 & Yes & 56 (19.6) & $23(24.2)$ & NR \\
\hline & & PGT122 & IGHV4-59 & D3-3 & $\mathrm{J} 6 * 03$ & 26 & Yes & 56 (19.6) & $25(26.3)$ & NR \\
\hline & & $10-1074$ & IGHV4-59 & D3-3 & $\mathrm{J} 6 * 03$ & 26 & ND & 45 (15.8) & $20(21.1)$ & NR \\
\hline & VRC24 & VRC24 & IGHV4-4 & D3-9 & $\mathrm{J} 5 * 02$ & 26 & ND & $64(22.5)$ & $29(30.2)$ & NR \\
\hline \multirow{5}{*}{$\begin{array}{l}\text { Glycan-related, gp120/ } \\
\text { gp41 bridging region }\end{array}$} & 8ANC195 & 8ANC195 & IGHV1-3 & D3-3*01 & $\mathrm{J} 4{ }^{*} 02$ & 22 & ND & $80(28.4)$ & $40(42.6)$ & Yes \\
\hline & PGT151 & PGT151 & IGHV3-30* & & J6*02 & 28 & ND & $60(20.8)$ & $27(28.1)$ & Neg.R \\
\hline & & PGT152 & IGHV3-30 & & $\mathrm{J} 6^{*} 02$ & 28 & ND & 56 (19.6) & $29(30.2)$ & Neg.R \\
\hline & & PGT154 & IGHV3-30 & & $\mathrm{J} 6{ }^{*} 02$ & 28 & ND & $53(18.4)$ & $25(26.0)$ & NR \\
\hline & & PGT158 & IGHV3-30 & & $\mathrm{J} 6{ }^{*} 02$ & 28 & ND & $61(21.2)$ & $30(31.2)$ & NR \\
\hline
\end{tabular}


Table 1 | Continued

\begin{tabular}{|c|c|c|c|c|c|c|c|c|c|c|}
\hline \multirow{2}{*}{$\begin{array}{l}\text { Category based on } \\
\text { epitope cluster }\end{array}$} & \multicolumn{2}{|c|}{ HIV-1 bnAb } & \multicolumn{3}{|c|}{ Heavy chain genes } & \multicolumn{2}{|c|}{ HCDR3 (IMGT) } & \multicolumn{2}{|c|}{ VH somatic mutation } & \multirow{2}{*}{$\begin{array}{l}\text { Auto/poly } \\
\text { reactivity** }\end{array}$} \\
\hline & Class & Clone & V gene & D gene & J gene & Length & $\begin{array}{l}\text { Potential VH } \\
\text { replacement* }\end{array}$ & $\begin{array}{l}\text { No. of } \\
\text { nt }(\%)\end{array}$ & $\begin{array}{l}\text { No. of } \\
\text { AA (\%) }\end{array}$ & \\
\hline \multirow[t]{4}{*}{ gp41 MPER } & MPER & $4 \mathrm{E} 10$ & IGHV1-69 & D1-1 & $\mathrm{J} 4{ }^{*} 02$ & 20 & ND & $19(6.6)$ & $18(18.8)$ & Yes \\
\hline & & $2 F 5$ & IGHV2-5 & D3-3 & $\mathrm{J} 6 * 02$ & 24 & ND & $41(14.1)$ & $14(14.4)$ & Yes \\
\hline & & 10E8 & IGHV3-15 & D3-3 & $\mathrm{J} 1{ }^{*} 01$ & 22 & ND & $63(21.4)$ & $26(26.5)$ & Neg.R \\
\hline & & M66.6 & IGHV5-51 & D3-10 & $\mathrm{J} 6 * 02$ & 23 & ND & $11(3.8)$ & $9(9.4)$ & Yes \\
\hline
\end{tabular}

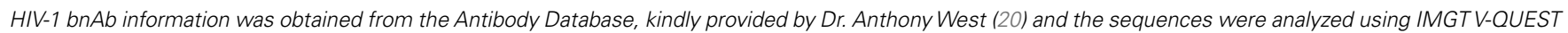
(51).

*Potential VH replacement footprints were determined as reported (52). ND, not determined.

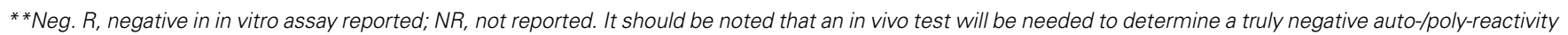

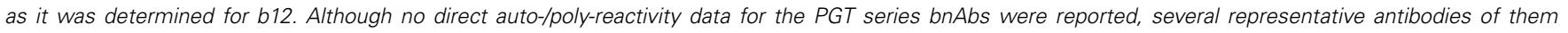

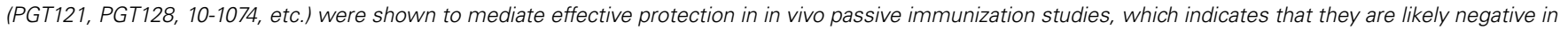
auto-/poly-reactivity.

the HIV-1 bnAbs also have insertions and deletions in their complementarity-determining regions (CDRs) $(17,26)$. This may reflect their prolonged, complex maturation path in vivo (17, $26,56,57$ ), which would require extensive activity of activationinduced cytidine deaminase (AID) in germinal center B cells (58). Thus, induction of such highly somatically mutated antibody responses by vaccination is obviously a major challenge for bnAb-based HIV-1 vaccine development $(20,50)$.

The second feature is that many of the HIV-1 bnAbs are auto/poly reactive $(26,28,31,32,59,60)$. This might be a property acquired in the development of $\mathrm{HIV}-1$ specific $\mathrm{B}$ cells during chronic HIV-1 infection that bypasses multiple B cell tolerance checkpoints $(37,61,62)$. This phenomenon might be one of the reasons why a bnAb is usually generated after prolonged exposure to viral antigen in some HIV-1 infected people $(26,61,62)$. Whether the auto/poly reactivity of these HIV-1 bnAbs is severe enough to prevent the induction of these antibodies in vivo in healthy individuals, which could be determined by in vivo testing of antibody gene knock-in animal models (63), will be critical to the success of a vaccine targeting these bnAbs (59). Alternatively, bnAbs with no or minimal auto/poly reactivity should be chosen as templates for HIV-1 vaccine $(18,24,53,61)$.

Another interesting feature is that many of the HIV-1 bnAbs have long (20-34 residues) heavy chain complementaritydetermining region 3 (HCDR3) sequences (Table 1), especially in antibodies of the glycan-related V1/V2 and V3 category (Supersite group), the gp120/gp41 bridging region category and the gp41-MPER category. This contrasts with an average length of 16 residues of HCDR3 in human B cells (54). The HCDR3s of CD4bs bnAbs are relatively short (Table 1). The PG9-like and PGT128-like bnAbs in the Supersite group appear to have a long HCDR3 that can penetrate the glycan shield of the Env trimer and interact with the V1/V2 and/or V3 region of gp120. The new MPER targeting 10E8 also uses a long CDRH3 loop to reach the highly conserved hydrophobic residues on gp41 (42-44, 53). A bias against long HCDR3s during B cell development has been demonstrated in mice and rabbits $(64,65)$, which complicates using small animal species as an HIV-1 bnAb-based vaccination model (66). Although humans do generate antibodies with very long HCDR3s (67), the lower frequency of B cells encoding long HCDR3s and the potential bias of auto-reactivity were viewed as a challenge for eliciting bnAbs of long HCDR3s by vaccination due to the negative regulation of these antibodies during B cell development (14, 19, 37, 53, 64, 66). However, it should be noted that, although many long HCDR3 antibodies were reported to be auto-reactive and $\mathrm{B}$ cell precursors of auto-reactive antibodies are under negative selection during $\mathrm{B}$ cell development (37), the long HCDR3 and the auto-reactivity are two distinct aspects of antibodies. It is neither true that all long HCDR3 antibodies are auto-reactive, nor that all autoreactive antibodies have long $\mathrm{HCDR} 3 \mathrm{~s}$, though a long HCDR3 and auto-reactivity can sometimes be present in the same antibody. Data with HIV-1 bnAbs indicate that the negative selection against $\mathrm{B}$ cells encoding long HCDR3s is most likely a result of negative selection against auto-reactivity instead of the long HCDR3 itself. Many of the long HCDR3 bnAbs in the "Supersite" group of HIV-1 bnAbs and the PGT151 series bnAbs are not auto/poly reactive, while the CD4bs bnAbs group has many auto/poly reactive antibodies with shorter HCDR3s [Table 1 and review of (60)]. B cell precursors of non-auto-reactive long HCDR3 antibodies can pass negative selection checkpoints to become mature B cells. This view is strongly supported by the recent observation that long $\mathrm{HCDR} 3 \mathrm{~s}$ are present in significant numbers in the human naïve $\mathrm{B}$ cell repertoire and that they are primarily generated by the recombination events during $\mathrm{B}$ cell development (68).

Here, we review the current literature on the immunologic mechanisms for the generation of antibodies with long HCDR3s, among which potential $\mathrm{VH}$ replacement products appear to make a significant contribution in the generation of HIV-1 bnAbs. Our view is that, though negatively selected during B cell development, long HCDR3s are not necessarily an obstacle in the development of an HIV-1 vaccine targeting long HCDR3 bnAb responses. 
IMMUNOLOGIC MECHANISMS FOR GENERATING

\section{ANTIBODIES WITH LONG HCDR3}

HCDR3, a key determinant of antibody specificity (69), is a product of combinatorial rearrangement of the variable $(\mathrm{V})$, diversity (D), and joining (J) gene segments. It is composed of the sequence from the $\mathrm{V}-\mathrm{D}$ junction, the $\mathrm{D}$ region, the $\mathrm{D}-\mathrm{J}$ junction and the $5^{\prime}$ end of the J gene. The alternative use of $\mathrm{D}$ reading frames, variation in junction sites due to P-nucleotides and addition of $\mathrm{N}$-nucleotides, in addition to VDJ recombination and somatic hypermutation (SHM), contribute to HCDR3 diversity $(70,71)$. Secondary mechanisms of receptor editing/revision, gene conversion, and $\mathrm{VH}$ replacement also contribute to the HCDR3 diversity (72-75). Among the diversities of HCDR3, the length of HCDR3 can have a large impact on the function of the antibody repertoire and varies from mouse to human $(64,65)$. Four immunologic mechanisms have been described that can increase the length of HCDR3.

\section{CONTRIBUTION OF SOMATIC HYPERMUTATION TO LONG HCDR3s}

The accumulation of insertions introduced during the SHM process can theoretically increase the length of $\operatorname{HCDR} 3(76,77)$. SHM related insertion/deletions (In/Dels) contribute substantially to the diversity of the human antibody repertoire, with an estimated frequency of $1.3-6.5 \%$ in circulating B cells, though short (1-2 residues) insertions are much more frequent than long insertions $(77,78)$. Interestingly, In/Dels from somatic mutation play a critical role in some bnAbs against HIV-1. The VRC01-like CH31class bnAbs (Table 1) have a nine-residue insertion in H-CDR1 (32). The VRC06 bnAb has a seven-residue insertion in H-FR3 (33). The PGT128-class bnAbs have a 5-6 residue insertion in H-CDR2 (29). However, the contribution of SHM related insertion to long HCDR3s is hard to assign due to the complex nature of VDJ junctions. A convincing result from an in depth analysis of HCDR3 length by next-generation sequencing demonstrated that SHM typically does not alter the length of HCDR3 and long HCDR3s are not generated primarily through SHM related insertions (68).

\section{LONG HCDR3s USUALLY ARISE DURING VDJ RECOMBINATION}

B cell precursors with long HCDR3s tend to be auto-reactive and are negatively selected during B cell development, which is a recognized mechanism for the bias against long HCDR3s in human mature B cell repertoire (37). However, deep sequencing the human HCDR3 repertoire revealed that long HCDR3s are present in the mature naïve $\mathrm{B}$ cell repertoire at a significant frequency (68). The naïve B cell pool contains $3.5 \%$ B cells of HCDR3s $\geq 24$ residues and $0.43 \%$ B cells of very long HCDR3s ( $\geq 28$ residues). The features of $\mathrm{P}$ - and $\mathrm{N}$-addition length from VDJ recombination show positive correlations with increasing HCDR3 length. Further, the B cells encoding long HCDRs display biased germline gene usage. Long HCDR3s show a strong association with the use of the D2 (D2-2 and D2-15) and D3 (D3-3) gene families and the use of J6 gene segment. Interestingly, many of the HIV-1 bnAbs with long HCDR3s use these preferred D and J gene segments. The PG9-class and PGT121-class bnAbs use the D3-3 and J6 gene segments and show very long HCDR3s (Table 1). It should be noted that these long HCDR3-associated human D and J gene segments are substantially longer than other D and J gene segments (68). Small animals such as mice and rabbits do not have similar long D and J gene segments, which might be why they do not generate antibodies with long HCDR3s and why small animal species are not considered suitable as HIV-1 bnAb-based vaccination models (66). This further supports the idea that long HCDR3s are established in humans primarily during VDJ recombination before the antigen-driven affinity maturation process.

\section{D-D FUSION RECOMBINANTS CAN GENERATE LONG HCDR3s}

$\mathrm{D}-\mathrm{D}$ fusion is a $\mathrm{V}(\mathrm{DD}) \mathrm{J}$ recombination event that allows the generation of extremely long HCDR3s. D-D fusions are difficult to produce through normal $\mathrm{V}(\mathrm{D}) \mathrm{J}$ recombination because they violate the $12 / 23$ rule (79). Although rare, these non-12/23 recombination events have been reported in in vitro and in vivo systems (80-82). High-throughput deep sequencing demonstrated that the frequency of D-D fusion in the naïve B cell population is about 1 in 800 naive B cells (79). The frequency is reduced in memory B cells. However, due to potential mismatches from somatic hypermutation, it is a challenge to accurately determine the frequency of D-D fusion in somatic-mutated memory B cells. The contribution of D-D fusion to long HCDR3s of HIV-1 bnAbs is unknown because almost all the bnAbs exhibit extensive hypermutation that make it hard to accurately match the germline $\mathrm{D}$ gene segments of HIV-1 bnAbs. HIV-1 bnAbs of PGT145 and PG9 classes (Table 1) have extremely long HCDR3s (34 and 30 residues, respectively) and are highly somatically mutated. IMGT junction analysis (51) of the HCDR3 of PGT145 reveals a $12 \mathrm{bp}$ D4-17 sequence with three mismatches as well as an 11 bp D5-24 sequence with two mismatches, indicating that the long HCD3 of PGT145 might be the product of a D-D fusion. Therefore, it is possible that some HIV-1 bnAbs are derived from naïve B cells with D-D fusions.

\section{VH REPLACEMENT CONTRIBUTES SIGNIFICANTLY TO LONG HCDR3}

$\mathrm{VH}$ replacement is a well-recognized mechanism of antibody gene rearrangement $(73,83)$. It occurs through recombinase activated gene (RAG)-mediated secondary recombination (84) and contributes to the diversified naïve $B$ cell repertoire (85). It is a process in which secondary $\mathrm{V}-\mathrm{V}(\mathrm{D}) \mathrm{J}$ recombination results in replacement of the variable gene while preserving the original D-J recombination. It appears to occur early in $\mathrm{B}$ cell development as a mechanism to rescue non-functional and unwanted IgH genes to further diversify the $\mathrm{IgH}$ repertoire (86-88). The secondary recombination during VH replacement involves a cryptic recombination signal sequence (RSS) within a previously rearranged $\mathrm{V}(\mathrm{D}) \mathrm{J}$ joint with a 23 bp RSS from an upstream invading VH gene (86). During this process, a short stretch of nucleotides from previously rearranged $\mathrm{VH}$ genes are left within the newly formed HCDR3 and, therefore, elongate the HCDR3 region and provide a potentially identifiable "footprint" of $\mathrm{VH}$ replacement $(75,89)$.

By footprint analysis, the frequency of $\mathrm{VH}$ replacement in normal peripheral B cells was estimated to be $5.7 \%$ (52), which 
is significantly higher than that of D-D fusions. Although not all $\mathrm{VH}$ replacements necessarily result in $\mathrm{VH}$ genes with long HCDR3s, a high frequency of anti-HIV antibodies contain potential VH replacement footprints and many of these antibodies also have long HCDR3s (52). Seventy-three percent of anti-HIV CD4 induced (CD4i) antibodies and all PGT-class bnAbs (Table 1) contain $\mathrm{VH}$ replacement footprints. Both CD4i and PGT antibodies tend to be encoded by $\operatorname{IgH}$ genes of long HCDR3s, which are used to reach recessed regions of the $\operatorname{Env}(39,52)$. These observations indicate that $\mathrm{VH}$ replacement may contribute significantly to HIV-1 antibodies that use long HCDR3s.

However, the detection of $\mathrm{VH}$ replacement by footprint analysis is controversial. Footprint determination of $\mathrm{VH}$ replacement could result in false positives because footprints can be mimicked by processes other than $\mathrm{VH}$ replacement, such as $\mathrm{N}$-addition $(72,90)$. It could also result in false negative sequences because not every $\mathrm{VH}$ replacement products will have a detectable footprint $(85,90)$. Yet, footprint analysis is currently the only available choice for $\mathrm{VH}$ replacement studies on human primary samples and there is no question that $\mathrm{VH}$ replacement can generate antibodies with long HCDR3s.

\section{DISCUSSION}

Three of the four potential immunologic mechanisms for the generation of antibodies with long HCDR3s occur mainly at the time of $\mathrm{V}(\mathrm{D}) \mathrm{J}$ recombination during primary $\mathrm{B}$ cell development. There are $3.5 \% \mathrm{~B}$ cells with $\mathrm{HCDR} 3 \mathrm{~s} \geq 24$ amino acid residues and $0.43 \%$ B cells with very long HCDR3s ( $\geq 28$ residues) in the naive $\mathrm{B}$ cell population (68). This is a significant number when one considers the total of more than $10^{12}$ potentially different antibodies in the human B cell repertoire. Therefore, long HCDR3s, while relatively low in frequency, are a normal part of the naïve $B$ cell repertoire that can actively participate in humoral immune responses. B cells with long HCDR3s appear to be selected by Env antigens to generate HIV-1 bnAbs targeting conserved epitopes located within deep regions of the HIV-1 envelope trimer. Long HCDR3s alone should not necessarily be viewed as an obstacle to the development of an HIV-1 vaccine targeting the long HCDR3 bnAb responses. Yet, how to induce highly mutated and autoreactive HIV-1 bnAb response remains a true challenge for HIV-1 vaccine development (60).

The high frequency of $\mathrm{VH}$ replacement footprints in many HIV-1 bnAbs suggests a new strategy for HIV-1 vaccine development; we should first understand the mechanism regulating $\mathrm{VH}$ replacement events during B cell development $(90,91)$ and then find a safe procedure to increase the frequency of $\mathrm{VH}$ replacement events before immunization. This strategy should increase the frequency of long HCDR3 germline B cells of HIV-1 bnAbs in the naïve $\mathrm{B}$ cell pool, which, in turn, may improve the potential of generating bnAb responses against HIV-1. Increasing the frequency of long HCDR3-containing B cells through manipulating the level of $\mathrm{VH}$ replacement may lead to more opportunities in generating bnAbs of long $\mathrm{CDRH} 3 \mathrm{~s}$. But this remains to be tested because increasing the frequency of HIV-1 bnAbs' germline B cells may not be sufficient to generate bnAb responses.

Recent studies on the generation of HIV-1 bnAbs in HIV1 infected individuals have highlighted the co-evolution of the
HIV-1 Env diversity and the breadth of neutralizing antibody responses against $\operatorname{Env}(26,56,57,92)$, which indicates an antigendriven pathway for HIV-1 bnAbs. Since it was demonstrated that Envs from different HIV-1 strains are not equal in activating HIV1 bnAbs' germline B cells $(26,57,93)$, a proper Env antigen with the right conformational epitopes may be required to activate HIV-1 bnAb germline B cells $(61,94)$ that presumably exist in most healthy individuals. Many of the HIV-1 bnAbs with long HCDR3s, such as PG9 and PGT151, recognize conformational epitopes that are not well exposed in recombinant gp120 or gp140 $(30,46)$. Therefore, the construction of recombinant Env proteins of native gp140 trimers (39) and/or constrained gp120s (95) that can preferentially expose epitopes recognized by bnAbs would be good antigen candidates in this regard. Further, a proper immunization strategy, such as sequential immunizations with selected diverse Env antigens and proper follicular helper T cells, will likely be required to drive the antibody responses toward highly mutated bnAbs $(17,20,50)$.

\section{ACKNOWLEDGMENTS}

We would like to thank Dr. George Lewis for helpful conversations, Dr. Marvin Reitz and Dr. Brian Taylor for editing the manuscript. We thank Dr. Anthony West for sharing the Antibody Database [version 2.0(5)]. Yongjun Guan was supported in part by grants 1R56AI098576 and R01AI087181 from NIAID, NIH, and by Grant \#OPP1033109 from the Bill and Melinda Gates Foundation.

\section{REFERENCES}

1. Baba TW, Liska V, Hofmann-Lehmann R, Vlasak J, Xu W, Ayehunie S, et al. Human neutralizing monoclonal antibodies of the IgG1 subtype protect against mucosal simian-human immunodeficiency virus infection. Nat Med (2000) 6:200-6. doi:10.1038/72309

2. Balazs AB, Ouyang Y, Hong CM, Chen J, Nguyen SM, Rao DS, et al. Vectored immunoprophylaxis protects humanized mice from mucosal HIV transmission. Nat Med (2014) 20:296-300. doi:10.1038/nm.3471

3. Barouch DH, Whitney JB, Moldt B, Klein F, Oliveira TY, Liu J, et al. Therapeutic efficacy of potent neutralizing HIV-1-specific monoclonal antibodies in SHIV-infected rhesus monkeys. Nature (2013) 503:224-8. doi:10.1038/ nature 12744

4. Hessell AJ, Poignard P, Hunter M, Hangartner L, Tehrani DM, Bleeker WK, et al. Effective, low-titer antibody protection against low-dose repeated mucosal SHIV challenge in macaques. Nat Med (2009) 15:951-4. doi:10.1038/nm.1974

5. Horwitz JA, Halper-Stromberg A, Mouquet H, Gitlin AD, Tretiakova A, Eisenreich TR, et al. HIV-1 suppression and durable control by combining single broadly neutralizing antibodies and antiretroviral drugs in humanized mice. Proc Natl Acad Sci U S A (2013) 110:16538-43. doi:10.1073/pnas. 1315295110

6. Klein F, Halper-Stromberg A, Horwitz JA, Gruell H, Scheid JF, Bournazos S, et al. HIV therapy by a combination of broadly neutralizing antibodies in humanized mice. Nature (2012) 492:118-22. doi:10.1038/nature11604

7. Mascola JR, Lewis MG, Stiegler G, Harris D, VanCott TC, Hayes D, et al. Protection of Macaques against pathogenic simian/human immunodeficiency virus 89.6PD by passive transfer of neutralizing antibodies. J Virol (1999) 73:4009-18.

8. Moldt B, Rakasz EG, Schultz N, Chan-Hui PY, Swiderek K, Weisgrau KL, et al. Highly potent HIV-specific antibody neutralization in vitro translates into effective protection against mucosal SHIV challenge in vivo. Proc Natl Acad Sci U S A (2012) 109:18921-5. doi:10.1073/pnas.1214785109

9. Shibata R, Igarashi T, Haigwood N, Buckler-White A, Ogert R, Ross W, et al. Neutralizing antibody directed against the HIV-1 envelope glycoprotein can completely block HIV-1/SIV chimeric virus infections of macaque monkeys. Nat Med (1999) 5:204-10. doi:10.1038/5568 
10. Shingai M, Nishimura Y, Klein F, Mouquet H, Donau OK, Plishka R, et al. Antibody-mediated immunotherapy of macaques chronically infected with SHIV suppresses viraemia. Nature (2013) 503:277-80. doi:10.1038/nature12746

11. Veazey RS, Shattock RJ, Pope M, Kirijan JC, Jones J, Hu Q, et al. Prevention of virus transmission to macaque monkeys by a vaginally applied monoclonal antibody to HIV-1 gp120. Nat Med (2003) 9:343-6. doi:10.1038/nm833

12. Burton DR, Poignard P, Stanfield RL, Wilson IA. Broadly neutralizing antibodies present new prospects to counter highly antigenically diverse viruses. Science (2012) 337:183-6. doi:10.1126/science.1225416

13. Haynes BF, McElrath MJ. Progress in HIV-1 vaccine development. Curr Opin HIV AIDS (2013) 8:326-32. doi:10.1097/COH.0b013e328361d178

14. Koff WC. HIV vaccine development: challenges and opportunities towards solving the HIV vaccine-neutralizing antibody problem. Vaccine (2011) 30(29):4310-5. doi:10.1016/j.vaccine.2011.11.014

15. Kwong PD, Mascola JR, Nabel GJ. The changing face of HIV vaccine research. J Int AIDS Soc (2012) 15:17407. doi:10.7448/IAS.15.2.17407

16. Kwong PD, Mascola JR, Nabel GJ. Broadly neutralizing antibodies and the search for an HIV-1 vaccine: the end of the beginning. Nat Rev Immunol (2013) 13:693-701. doi:10.1038/nri3516

17. Mouquet H, Nussenzweig MC. HIV: roadmaps to a vaccine. Nature (2013) 496:441-2. doi:10.1038/nature12091

18. Sattentau QJ, McMichael AJ. New templates for HIV-1 antibody-based vaccine design. F1000 Biol Rep (2010) 2:60. doi:10.3410/B2-60

19. Stamatatos L. HIV vaccine design: the neutralizing antibody conundrum. Curr Opin Immunol (2012) 24:316-23. doi:10.1016/j.coi.2012.04.006

20. West AP Jr, Scharf L, Scheid JF, Klein F, Bjorkman PJ, Nussenzweig MC. Structural insights on the role of antibodies in HIV-1 vaccine and therapy. Cell (2014) 156:633-48. doi:10.1016/j.cell.2014.01.052

21. Bonsignori M, Hwang KK, Chen X, Tsao CY, Morris L, Gray E, et al. Analysis of a clonal lineage of HIV-1 envelope V2/V3 conformational epitope-specific broadly neutralizing antibodies and their inferred unmutated common ancestors. J Virol (2011) 85:9998-10009. doi:10.1128/JVI.05045-11

22. Corti D, Langedijk JP, Hinz A, Seaman MS, Vanzetta F, Fernandez-Rodriguez $\mathrm{BM}$, et al. Analysis of memory B cell responses and isolation of novel monoclonal antibodies with neutralizing breadth from HIV-1-infected individuals. PLoS One (2010) 5:e8805. doi:10.1371/journal.pone.0008805

23. Georgiev IS, Doria-Rose NA, Zhou T, Kwon YD, Staupe RP, Moquin S, et al. Delineating antibody recognition in polyclonal sera from patterns of HIV-1 isolate neutralization. Science (2013) 340:751-6. doi:10.1126/science.1233989

24. Huang J, Ofek G, Laub L, Louder MK, Doria-Rose NA, Longo NS, et al. Broad and potent neutralization of HIV-1 by a gp41-specific human antibody. Nature (2012) 491:406-12. doi:10.1038/nature11544

25. LiY, O'Dell S, Wilson R, Wu X, Schmidt SD, Hogerkorp CM, et al. HIV-1 neutralizing antibodies display dual recognition of the primary and coreceptor binding sites and preferential binding to fully cleaved envelope glycoproteins. J Virol (2012) 86:11231-41. doi:10.1128/JVI.01543-12

26. Liao HX, Lynch R, Zhou T, Gao F, Alam SM, Boyd SD, et al. Co-evolution of a broadly neutralizing HIV-1 antibody and founder virus. Nature (2013) 496:469-76. doi:10.1038/nature 12053

27. Scheid JF, Mouquet H, Feldhahn N, Seaman MS, Velinzon K, Pietzsch J, et al. Broad diversity of neutralizing antibodies isolated from memory B cells in HIVinfected individuals. Nature (2009) 458:636-40. doi:10.1038/nature07930

28. Scheid JF, Mouquet H, Ueberheide B, Diskin R, Klein F, Oliveira TY, et al. Sequence and structural convergence of broad and potent HIV antibodies that mimic CD4 binding. Science (2011) 333:1633-7. doi:10.1126/science.1207227

29. Walker LM, Huber M, Doores KJ, Falkowska E, Pejchal R, Julien JP, et al. Broad neutralization coverage of HIV by multiple highly potent antibodies. Nature (2011) 477:466-70. doi:10.1038/nature10373

30. Walker LM, Phogat SK, Chan-Hui PY, Wagner D, Phung P, Goss JL, et al. Broad and potent neutralizing antibodies from an African donor reveal a new HIV-1 vaccine target. Science (2009) 326:285-9. doi:10.1126/science.1178746

31. Wu X, Yang ZY, Li Y, Hogerkorp CM, Schief WR, Seaman MS, et al. Rational design of envelope identifies broadly neutralizing human monoclonal antibodies to HIV-1. Science (2010) 329:856-61. doi:10.1126/science.1187659

32. Wu X, Zhou T, Zhu J, Zhang B, Georgiev I, Wang C, et al. Focused evolution of HIV-1 neutralizing antibodies revealed by structures and deep sequencing. Science (2011) 333:1593-602. doi:10.1126/science.1207532
33. Zhou T, Zhu J, Wu X, Moquin S, Zhang B, Acharya P, et al. Multidonor analysis reveals structural elements, genetic determinants, and maturation pathway for HIV-1 neutralization by VRC01-class antibodies. Immunity (2013) 39:245-58. doi:10.1016/j.immuni.2013.04.012

34. Chang TW. Selecting low frequency antigen-specific single B lymphocytes. In: Ueberheide B, editor. United States Patent Number 5326696. Houston, TX: Tanox Biosystems, Inc. (1994).

35. Scheid JF, Mouquet H, Feldhahn N, Walker BD, Pereyra F, Cutrell E, et al. A method for identification of HIV gp140 binding memory B cells in human blood. J Immunol Methods (2009) 343:65-7. doi:10.1016/j.jim.2008.11.012

36. Simek MD, Rida W, Priddy FH, Pung P, Carrow E, Laufer DS, et al. Human immunodeficiency virus type 1 elite neutralizers: individuals with broad and potent neutralizing activity identified by using a high-throughput neutralization assay together with an analytical selection algorithm. J Virol (2009) 83:7337-48. doi:10.1128/JVI.00110-09

37. Wardemann H, Yurasov S, Schaefer A, Young JW, Meffre E, Nussenzweig MC. Predominant autoantibody production by early human B cell precursors. Science (2003) 301:1374-7. doi:10.1126/science.1086907

38. Doores KJ, Fulton Z, Huber M, Wilson IA, Burton DR. Antibody 2 G12 recognizes di-mannose equivalently in domain- and nondomain-exchanged forms but only binds the HIV-1 glycan shield if domain exchanged. J Virol (2010) 84:10690-9. doi:10.1128/JVI.01110-10

39. Julien JP, Cupo A, Sok D, Stanfield RL, Lyumkis D, Deller MC, et al. Crystal structure of a soluble cleaved HIV-1 envelope trimer. Science (2013) 342:1477-83. doi:10.1126/science. 1245625

40. Lyumkis D, Julien JP, de Val N, Cupo A, Potter CS, Klasse PJ, et al. Cryo-EM structure of a fully glycosylated soluble cleaved HIV-1 envelope trimer. Science (2013) 342:1484-90. doi:10.1126/science.1245627

41. Zhou T, Xu L, Dey B, Hessell AJ, Van Ryk D, Xiang SH, et al. Structural definition of a conserved neutralization epitope on HIV-1 gp120. Nature (2007) 445:732-7. doi:10.1038/nature05580

42. Kong L, Lee JH, Doores KJ, Murin CD, Julien JP, McBride R, et al. Supersite of immune vulnerability on the glycosylated face of HIV-1 envelope glycoprotein gp120. Nat Struct Mol Biol (2013) 20(7):796-803. doi:10.1038/nsmb.2594

43. Mouquet H, Scharf L, Euler Z, Liu Y, Eden C, Scheid JF, et al. Complex-type $\mathrm{N}$-glycan recognition by potent broadly neutralizing HIV antibodies. Proc Natl Acad Sci U S A (2012) 109:E3268-77. doi:10.1073/pnas.1217207109

44. Pejchal R, Doores KJ, Walker LM, Khayat R, Huang PS, Wang SK, et al. A potent and broad neutralizing antibody recognizes and penetrates the HIV glycan shield. Science (2011) 334:1097-103. doi:10.1126/science.1213256

45. Blattner C, Lee JH, Sliepen K, Derking R, Falkowska E, de la Pena AT, et al. Structural delineation of a quaternary, cleavage-dependent epitope at the gp41gp120 interface on intact HIV-1 Env trimers. Immunity (2014) 40:669-80. doi:10.1016/j.immuni.2014.04.008

46. Falkowska E, Le KM, Ramos A, Doores KJ, Lee JH, Blattner C, et al. Broadly neutralizing HIV antibodies define a glycan-dependent epitope on the prefusion conformation of gp41 on cleaved envelope trimers. Immunity (2014) 40:657-68. doi:10.1016/j.immuni.2014.04.009

47. Scharf L, Scheid JF, Lee JH, West AP Jr, Chen C, Gao H, et al. Antibody 8ANC195 reveals a site of broad vulnerability on the HIV-1 envelope spike. Cell Rep (2014) 7(3):785-95. doi:10.1016/j.celrep.2014.04.001

48. Buchacher A, Predl R, Strutzenberger K, Steinfellner W, Trkola A, Purtscher $\mathrm{M}$, et al. Generation of human monoclonal antibodies against HIV-1 proteins; electrofusion and Epstein-Barr virus transformation for peripheral blood lymphocyte immortalization. AIDS Res Hum Retroviruses (1994) 10:359-69. doi:10.1089/aid.1994.10.359

49. Zhu Z, Qin HR, Chen W, Zhao Q, Shen X, Schutte R, et al. Cross-reactive HIV1-neutralizing human monoclonal antibodies identified from a patient with 2F5-like antibodies. J Virol (2011) 85:11401-8. doi:10.1128/JVI.05312-11

50. Mascola JR, Haynes BF. HIV-1 neutralizing antibodies: understanding nature's pathways. Immunol Rev (2013) 254:225-44. doi:10.1111/imr.12075

51. Lefranc MP, Giudicelli V, Ginestoux C, Jabado-Michaloud J, Folch G, Bellahcene F, et al. IMGT, the international ImMunoGeneTics information system. Nucleic Acids Res (2009) 37:D1006-12. doi:10.1093/nar/gkn838

52. Liao H, Guo JT, Lange MD, Fan R, Zemlin M, Su K, et al. Contribution of V(H) replacement products to the generation of anti-HIV antibodies. Clin Immunol (2013) 146:46-55. doi:10.1016/j.clim.2012.11.003 
53. Kwong PD, Mascola JR. Human antibodies that neutralize HIV-1: identification, structures, and B cell ontogenies. Immunity (2012) 37:412-25. doi:10.1016/j. immuni.2012.08.012

54. Tiller T, Tsuiji M, Yurasov S, Velinzon K, Nussenzweig MC, Wardemann H. Autoreactivity in human IgG+ memory B cells. Immunity (2007) 26:205-13. doi:10.1016/j.immuni.2007.01.009

55. Wrammert J, Koutsonanos D, Li GM, Edupuganti S, Sui J, Morrissey M, et al. Broadly cross-reactive antibodies dominate the human B cell response against 2009 pandemic H1N1 influenza virus infection. J Exp Med (2011) 208:181-93. doi:10.1084/jem.20101352

56. Moore PL, Gray ES, Wibmer CK, Bhiman JN, Nonyane M, Sheward DJ, et al. Evolution of an HIV glycan-dependent broadly neutralizing antibody epitope through immune escape. Nat Med (2012) 18:1688-92. doi:10.1038/nm.2985

57. Wibmer CK, Bhiman JN, Gray ES, Tumba N, Abdool Karim SS, Williamson C, et al. Viral escape from HIV-1 neutralizing antibodies drives increased plasma neutralization breadth through sequential recognition of multiple epitopes and immunotypes. PLoS Pathog (2013) 9:e1003738. doi:10.1371/journal.ppat. 1003738

58. Victora GD, Nussenzweig MC. Germinal centers. Annu Rev Immunol (2012) 30:429-57. doi:10.1146/annurev-immunol-020711-075032

59. Haynes BF, Fleming J, St Clair EW, Katinger H, Stiegler G, Kunert R, et al. Cardiolipin polyspecific autoreactivity in two broadly neutralizing HIV-1 antibodies. Science (2005) 308:1906-8. doi:10.1126/science.1111781

60. Verkoczy L, Diaz M. Autoreactivity in HIV-1 broadly neutralizing antibodies: implications for their function and induction by vaccination. Curr Opin HIV AIDS (2014) 9:224-34. doi:10.1097/COH.0000000000000049

61. Haynes BF, Kelsoe G, Harrison SC, Kepler TB. B-cell-lineage immunogen design in vaccine development with HIV-1 as a case study. Nat Biotechnol (2012) 30:423-33. doi:10.1038/nbt.2197

62. Mouquet H, Nussenzweig MC. Polyreactive antibodies in adaptive immune responses to viruses. Cell Mol Life Sci (2012) 69:1435-45. doi:10.1007/s00018011-0872-6

63. Ota T, Doyle-Cooper C, Cooper AB, Doores KJ, Aoki-Ota M, Le K, et al. B cells from knock-in mice expressing broadly neutralizing HIV antibody b12 carry an innocuous B cell receptor responsive to HIV vaccine candidates. J Immunol (2013) 191:3179-85. doi:10.4049/jimmunol.1301283

64. Wu TT, Johnson G, Kabat EA. Length distribution of CDRH3 in antibodies. Proteins (1993) 16:1-7. doi:10.1002/prot.340160102

65. Zemlin M, Klinger M, Link J, Zemlin C, Bauer K, Engler JA, et al. Expressed murine and human CDR-H3 intervals of equal length exhibit distinct repertoires that differ in their amino acid composition and predicted range of structures. J Mol Biol (2003) 334:733-49. doi:10.1016/j.jmb.2003.10.007

66. Ivanov II, Schelonka RL, Zhuang Y, Gartland GL, Zemlin M, Schroeder HW Jr. Development of the expressed Ig CDR-H3 repertoire is marked by focusing of constraints in length, amino acid use, and charge that are first established in early B cell progenitors. J Immunol (2005) 174:7773-80. doi:10.4049/jimmunol. 174.12.7773

67. Arnaout R, Lee W, Cahill P, Honan T, Sparrow T, Weiand M, et al. Highresolution description of antibody heavy-chain repertoires in humans. PLoS One (2011) 6:e22365. doi:10.1371/journal.pone.0022365

68. Briney BS, Willis JR, Crowe JE Jr. Human peripheral blood antibodies with long HCDR3s are established primarily at original recombination using a limited subset of germline genes. PLoS One (2012) 7:e36750. doi:10.1371/journal.pone. 0036750

69. Ohno S, Mori N, Matsunaga T. Antigen-binding specificities of antibodies are primarily determined by seven residues of VH. Proc Natl Acad Sci U S A (1985) 82:2945-9. doi:10.1073/pnas.82.9.2945

70. Bassing $\mathrm{CH}$, Swat W, Alt FW. The mechanism and regulation of chromosomal V(D)J recombination. Cell (2002) 109(Suppl):S45-55. doi:10.1016/S00928674(02)00675-X

71. Tonegawa S. Somatic generation of antibody diversity. Nature (1983) 302:575-81. doi:10.1038/302575a0

72. Briney BS, Crowe JE Jr. Secondary mechanisms of diversification in the human antibody repertoire. Front Immunol (2013) 4:42. doi:10.3389/fimmu.2013. 00042

73. Chen C, Nagy Z, Prak EL, Weigert M. Immunoglobulin heavy chain gene replacement: a mechanism of receptor editing. Immunity (1995) 3:747-55. doi:10.1016/1074-7613(95)90064-0
74. Wilson PC, Wilson K, Liu YJ, Banchereau J, Pascual V, Capra JD. Receptor revision of immunoglobulin heavy chain variable region genes in normal human B lymphocytes. J Exp Med (2000) 191:1881-94. doi:10.1084/jem.191. 11.1881

75. Zhang Z, Burrows PD, Cooper MD. The molecular basis and biological significance of VH replacement. Immunol Rev (2004) 197:231-42. doi:10.1111/j.01052896.2004.0107.x

76. Reason DC, Zhou J. Codon insertion and deletion functions as a somatic diversification mechanism in human antibody repertoires. Biol Direct (2006) 1:24. doi:10.1186/1745-6150-1-24

77. Wilson PC, de Bouteiller O, Liu YJ, Potter K, Banchereau J, Capra JD, et al. Somatic hypermutation introduces insertions and deletions into immunoglobulin V genes. J Exp Med (1998) 187:59-70. doi:10.1084/jem.187.1.59

78. Briney BS, Willis JR, Crowe JE Jr. Location and length distribution of somatic hypermutation-associated DNA insertions and deletions reveals regions of antibody structural plasticity. Genes Immun (2012) 13:523-9. doi:10.1038/gene. 2012.28

79. Briney BS, Willis JR, Hicar MD, Thomas JW II, Crowe JE Jr. Frequency and genetic characterization of $\mathrm{V}(\mathrm{DD}) \mathrm{J}$ recombinants in the human peripheral blood antibody repertoire. Immunology (2012) 137:56-64. doi:10.1111/j.1365-2567. 2012.03605.x

80. Klonowski KD, Primiano LL, Monestier M. Atypical VH-D-JH rearrangements in newborn autoimmune MRL mice. J Immunol (1999) 162:1566-72.

81. Sanz I. Multiple mechanisms participate in the generation of diversity of human H chain CDR3 regions. J Immunol (1991) 147:1720-9.

82. Watson LC, Moffatt-Blue CS, McDonald RZ, Kompfner E, Ait-Azzouzene D, Nemazee D, et al. Paucity of V-D-D-J rearrangements and VH replacement events in lupus prone and nonautoimmune TdT-/- and TdT $+/+$ mice. JImmunol (2006) 177:1120-8. doi:10.4049/jimmunol.177.2.1120

83. Darlow JM, Stott DI. V(H) replacement in rearranged immunoglobulin genes. Immunology (2005) 114:155-65. doi:10.1111/j.1365-2567.2004.02084.x

84. Zhang Z, Zemlin M, Wang YH, Munfus D, Huye LE, Findley HW, et al. Contribution of $\mathrm{VH}$ gene replacement to the primary $\mathrm{B}$ cell repertoire. Immunity (2003) 19:21-31. doi:10.1016/S1074-7613(03)00170-5

85. Koralov SB, Novobrantseva TI, Konigsmann J, Ehlich A, Rajewsky K. Antibody repertoires generated by $\mathrm{VH}$ replacement and direct $\mathrm{VH}$ to $\mathrm{JH}$ joining. Immunity (2006) 25:43-53. doi:10.1016/j.immuni.2006.04.016

86. Nemazee D. Receptor editing in lymphocyte development and central tolerance. Nat Rev Immunol (2006) 6:728-40. doi:10.1038/nri1939

87. Yunk L, Meng W, Cohen PL, Eisenberg RA, Luning Prak ET. Antibodies in a heavy chain knock-in mouse exhibit characteristics of early heavy chain rearrangement. J Immunol (2009) 183:452-61. doi:10.4049/jimmunol.0804060

88. Zhang Z. VH replacement in mice and humans. Trends Immunol (2007) 28:132-7. doi:10.1016/j.it.2007.01.003

89. Huang L, Lange MD, Zhang Z. VH replacement footprint analyzer-I, a javabased computer program for analyses of immunoglobulin heavy chain genes and potential VH replacement products in human and mouse. Front Immunol (2014) 5:40. doi:10.3389/fimmu.2014.00040

90. Meng W, Jayaraman S, Zhang B, Schwartz GW, Daber RD, Hershberg U, et al. Trials and tribulations with VH replacement. Front Immunol (2014) 5:10. doi:10.3389/fimmu.2014.00010

91. Liu J, Lange MD, Hong SY, Xie W, Xu K, Huang L, et al. Regulation of VH replacement by B cell receptor-mediated signaling in human immature B cells. J Immunol (2013) 190:5559-66. doi:10.4049/jimmunol.1102503

92. Doria-Rose NA, Schramm CA, Gorman J, Moore PL, Bhiman JN, DeKosky BJ, et al. Developmental pathway for potent V1V2-directed HIV-neutralizing antibodies. Nature (2014) 509:55-62. doi:10.1038/nature13036

93. McGuire AT, Glenn JA, Lippy A, Stamatatos L. Diverse recombinant HIV-1 Envs fail to activate B cells expressing the germline B cell receptors of the broadly neutralizing anti-HIV-1 antibodies PG9 and 447-52D. J Virol (2014) 88:2645-57. doi:10.1128/JVI.03228-13

94. Jardine J, Julien JP, Menis S, Ota T, Kalyuzhniy O, McGuire A, et al. Rational HIV immunogen design to target specific germline B cell receptors. Science (2013) 340:711-6. doi:10.1126/science.1234150

95. Guan Y, Liu T, Sajadi MM, Yu L, Huang W, Seaman M, et al. A common transitional Env conformation revealed by a new broadly neutralizing antibody as a novel HIV-1 vaccine target. AIDS Vaccine 2013. Barcelona: (2013). $13.56 \mathrm{p}$. 
Conflict of Interest Statement: The authors declare that the research was conducted in the absence of any commercial or financial relationships that could be construed as a potential conflict of interest.

Received: 25 February 2014; accepted: 12 May 2014; published online: 02 June 2014. Citation: Yu L and Guan Y (2014) Immunologic basis for long HCDR3s in broadly neutralizing antibodies against HIV-1. Front. Immunol. 5:250. doi: 10.3389/fimmu.2014.00250
This article was submitted to B Cell Biology, a section of the journal Frontiers in Immunology.

Copyright (C) $2014 \mathrm{Yu}$ and Guan. This is an open-access article distributed under the terms of the Creative Commons Attribution License (CC BY). The use, distribution or reproduction in other forums is permitted, provided the original author(s) or licensor are credited and that the original publication in this journal is cited, in accordance with accepted academic practice. No use, distribution or reproduction is permitted which does not comply with these terms. 